\title{
Yield Compounds and Nutrient Elements of Carnation (Dianthus caryophyllus L.) under Different Growing Media
}

\author{
Mahsan Soltani, Davood Naderi* \\ Department of Horticulture, Isfahan (Khorasgan) Branch, Islamic Azad University, Isfahan, Iran \\ Email: *d.naderi@khuisf.ac.ir
}

Received 11 January 2016; accepted 20 March 2016; published 23 March 2016

Copyright (C) 2016 by authors and Scientific Research Publishing Inc.

This work is licensed under the Creative Commons Attribution International License (CC BY). http://creativecommons.org/licenses/by/4.0/

cc) (i) Open Access

\begin{abstract}
Production of cut flowers is very prevalent in Iran. Carnation is most famous for its use as a cut flower. This study was carried out in the research greenhouse of Islamic Azad University, Isfahan (Khorasgan) Branch, to explore the effect of different growing media on some vegetative and reproductive traits of carnation. The experimental design was randomized complete, using $\mathbf{5 0 \%}$ perlite and different growing media including: mineral soil and coco peat in 6 proportions $\mathbf{5 0 \%}$ coco peat, $10 \%$ soil $+40 \%$ coco peat, $20 \%$ soil $+30 \%$ coco peat, $30 \%$ soil $+20 \%$ coco peat, $40 \%$ soil $+\mathbf{1 0} \%$ coco peat, $50 \%$ soil). During growth period, irrigation rate, humidity and temperature were similar. The growth characteristics of carnation were determined at the end of growth period. The results indicated that although there were no significant differences between studied growing substrates in chlorophyll a, b. Statistical analysis showed fresh weight of flower was far greater in coco peat $10 \%+$ soil $40 \%$ and soil $50 \%$ compared to other growing media. Fresh and dry weight of root and shoot in soil $50 \%$ were higher than other growing media. The results showed that highest concentration of Fe and $\mathrm{Zn}$ was observed in coco peat $40 \%+$ soil $10 \%$. The concentration of $\mathrm{Mn}$ in coco peat $10 \%$ + soil $40 \%$ was higher than other growing media. The results showed that the highest Ca concentration was observed in soil $50 \%$ and the lowest concentration of this element was obtained in coco peat $50 \%$. According to the obtained results, mineral soil can be used as a suitable alternative to cocopeat for cultivation and growth of carnation in greenhouse.
\end{abstract}

\section{Keywords}

Cut Flower, Carnation, Mineral Soil, Coco Peat, Growing Media

\footnotetext{
${ }^{*}$ Corresponding author.
}

How to cite this paper: Soltani, M. and Naderi, D. (2016) Yield Compounds and Nutrient Elements of Carnation (Dianthus caryophyllus L.) under Different Growing Media. Open Journal of Ecology, 6, 184-191. 


\section{Introduction}

Carnation (Dianthus caryophyllus L.) has high ornamental value and easy technology for production of cut flower. It is the main floriculture crop in many countries. Carnation is most famous for its use as a cut flower. The carnation flower is a wonderful accent to bouquets and carnation home floral arrangements. An essential oil is obtained from carnation flowers, which is applied in perfumery where $500 \mathrm{Kg}$ of flower produce $100 \mathrm{gm}$ of oil. Also, the flower heads are dried and used in sachats and cosmetic. Carnation flowers are considered to be antispasmodic, cardiotonic, alexiteric, nervine, and diaphoretic [1]. According to previous studies, suitable growing media are necessary for gas exchange between plant roots and atmosphere, supply of nutrients and water quality flower production as well as sufficient anchorage of plant [2]. Porosity of growing media is an index for root media aeration. When root media aeration is suitable, supplement of nutrient elements and water for growth of plant is easily [3]. Nutrient availability is one of the important factors influencing the suitability of organic substrates for plant growth and development [4]. However, different growing substrates have several materials which could have effects on plant production. Thus, selecting the best substrate among the various materials is imperative to the plant productivity [5].

In previous studies such as Omidbaigi and Arjmandi [6] and Baranauskiene et al. [7], the application of chemical fertilizers for improve in crop yield is well confirmed. Also, few works showed that organic fertilizers resulted in increases in dry plant yield [8] [9]. Samiei et al. [10] examined the impacts of date-palm and peat moss wastes on growth traits of Aglaonema. They found both growing substrates were similar in some plant properties. Agriculture production needs sustainable and environmentally fertilizer management practices. Soil fertility is the most substantial and controlled factor affecting the nutritional content of plant. The production of organic food has been demonstrated to inhibit chemical fertilizers, herbicides, and pesticides and centralize on natural material and methods of controlling the plant growth, crop yield and plant diseases [11]. The organic fertilizers may serve as alternative practice to chemical fertilizers [12] for improving soil microbial activity [13] and soil structure [14]. With attention to rapid development of greenhouse cultivations for production of cut flowers such as carnation, the selection of a suitable substrate for cultivation and growth of carnation is required. Therefore, the aim of this study was to investigate the influence of these culture media on some vegetative and reproductive traits of carnation.

\section{Materials and Methods}

A greenhouse experiment was conducted at the research greenhouse of Isfahan (Khorasgan) branch during 8 months at 2013-2014 to explore the effect of different growing media on some vegetative and reproductive traits of carnation (Nuska). The experimental design was a completely randomized design replicated five times. The treatments were $50 \%$ perlite and different growing media including: mineral soil and coco peat in 6 proportions ( $50 \%$ coco peat, $10 \%$ soil $+40 \%$ coco peat, $20 \%$ soil $+30 \%$ coco peat, $30 \%$ soil $+20 \%$ coco peat, $40 \%$ soil + $10 \%$ coco peat, $50 \%$ soil). Plant saplings were planted in pots $(4 \mathrm{~L})$ filled with the above growing substrate. During growth period, humidity was similar. Average temperature of day and night were $25^{\circ} \mathrm{C} \pm 2^{\circ} \mathrm{C}$ and $17^{\circ} \mathrm{C} \pm$ $2^{\circ} \mathrm{C}$, respectively during growth period. The pots were irrigated three and two times in the spring-summer and autumn-winter seasons, respectively. Salt leeching by water was used to inhibition of salt accumulation. The concentration of nutrient elements in modified Hoagland for cultivation of carnation is listed in Table 1.

\subsection{Soil and Coco Peat Analysis}

The electrical conductivity (EC) in saturated extracts and soil $\mathrm{pH}$ was determined in the soil saturation paste. However, $\mathrm{pH}$ and EC of coco peat were measured in water extracts $(1: 5 \mathrm{v} / \mathrm{v})$. In soil and coco peat, total nitrogen (the Kejldahl method), available K (with ammonium acetate) available P (the Olsen's method) and cation exchange capacity (CEC) with NH4OAc method were determined via procedures described in Baruah and Barthakur

Table 1. The concentration (ppm) of nutrient elements in modified Hoagland.

\begin{tabular}{cccccccccccc}
\hline $\mathrm{EC}$ & $\mathrm{pH}$ & $\mathrm{N}$ & $\mathrm{P}$ & $\mathrm{K}$ & $\mathrm{Ca}$ & $\mathrm{Mg}$ & $\mathrm{Fe}$ & $\mathrm{Mn}$ & $\mathrm{Zn}$ & $\mathrm{Cu}$ & $\mathrm{B}$ \\
\hline$(\mathrm{dS} / \mathrm{m})$ & $(-)$ & & & \multicolumn{2}{c}{$(\mathrm{ppm})$} & & \\
& $5.5-6.5$ & 211 & 50 & 300 & 180 & 60 & 10 & 3 & 1.5 & 0.5 & 0.4 \\
\hline
\end{tabular}

EC: electrical conductivity. 
[15]. Also, the physical characteristics of soil and coco peat including water holding capacity [16], bulk density

[17] and porosity [15], were measured before planting. Soil texture was performed using the hydrometer method

[18]. Some chemical and physical properties of mineral soil and coco peat are listed in Table 2.

\subsection{Plant Analysis}

Some growth indices including fresh and dry weight of flower, shoot and root were determined at the end of growth period. Chlorophyll (Chl) was estimated by extracting the leaf material in $80 \%$ acetone. Absorbance was recorded at 663 and $645 \mathrm{~nm}$. Chl (a) and Chl (b) were calculated as described by Arnon [19]. The contents of nutrient elements in plant were determined by drying samples at $70^{\circ} \mathrm{C}$ and then ashed at $500^{\circ} \mathrm{C}$ under a gradual increase in temperature. Then, $10 \mathrm{~mL}$ hydrochloric acid $6 \mathrm{M}(1+1)$ was added and the solution was evaporated in water bath to dryness. The residue was dissolved in $50 \mathrm{~mL}$ distill water. The concentrations of $\mathrm{P}$ and $\mathrm{K}$ were measured by colorimetrically and flame photometry methods, respectively. Also, the concentrations of $\mathrm{Ca}, \mathrm{Mg}$ Fe, Mn and Zn were measured either by atomic absorption spectrophotometry (Perkin Elmer Analyst 800).

\subsection{Statistical Analysis}

One-way ANOVA was used to assess the effects of different growing media on all analyzed plant properties. Means were compared by Duncan test $(\mathrm{p}<0.05)$. Statistical procedures were carried out using the software package SAS 9.1 for Windows.

\section{Results}

\subsection{Flower Weight}

As shown at Table 3, the analysis of variance revealed that the effect of substrate on fresh and dry weight of flower was significant $(\mathrm{p}<0.01)$. Statistical analysis showed fresh weight of flower was far greater in coco peat $10 \%+$ soil $40 \%$ and soil $50 \%$ compared to other growing media (Table 3). However, dry weight of flower was far higher in soil $50 \%$ compared to other growing media. Reference to fresh and dry weight of flower, the differences between coco peat $50 \%$ with coco peat $20 \%+$ soil $30 \%$, coco peat $30 \%+$ soil $20 \%$ and coco peat $40 \%$ + soil $10 \%$ were not statistically different at $5 \%$ probability level, according to the Duncan test (Table 3 ).

\subsection{Root Weight}

There were significant $(\mathrm{p}<0.01)$ differences between culture media in fresh and dry weight of root. These properties in soil $50 \%$ were higher than other growing media, however the differences between other growing media were not statistically different at 5\% probability level, according to the Duncan test (Table 3).

Table 2. Some chemical and physical properties of mineral soil and coco peat.

\begin{tabular}{cccc}
\hline Parameters & Units & Soil & Coco peat \\
\hline EC & $(\mathrm{dS} / \mathrm{m})$ & 6.4 & 1.6 \\
$\mathrm{pH}$ & $(-)$ & 7.2 & 7.7 \\
Total nitrogen & $(\%)$ & 0.21 & 0.41 \\
Available P & $(\mathrm{mg} / \mathrm{kg})$ & 41.6 & 798.4 \\
Available K & $(\mathrm{mg} / \mathrm{kg})$ & 799.0 & 834.5 \\
CEC & $(\mathrm{cmol}+/ \mathrm{kg})$ & 24.43 & 75.0 \\
Bulk density & $\left(\mathrm{g} / \mathrm{cm}^{3}\right)$ & 1.35 & 0.93 \\
Particle density & $\left(\mathrm{g} / \mathrm{cm}^{3}\right)$ & 2.7 & 0.18 \\
Porosity & $(\%)$ & 50 & 66 \\
Texture & $(-)$ & Sandy clay loam & - \\
\hline
\end{tabular}

Note: EC: electrical conductivity, CEC: cation exchange capacity. 
Table 3. ANOVA model and comparison of flower, root and shoot weight (g) for different growing media.

\begin{tabular}{|c|c|c|c|c|c|c|c|}
\hline \multicolumn{8}{|c|}{ Mean values plant properties for different growing media } \\
\hline \multirow{2}{*}{\multicolumn{2}{|c|}{ Growing media }} & \multicolumn{2}{|c|}{ Flower } & \multicolumn{2}{|c|}{ Root } & \multicolumn{2}{|c|}{ Shoot } \\
\hline & & $\begin{array}{c}\text { Fresh weight } \\
\text { (g) }\end{array}$ & $\begin{array}{l}\text { Dry weight } \\
\text { (g) }\end{array}$ & $\begin{array}{c}\text { Fresh weight } \\
\text { (g) }\end{array}$ & $\begin{array}{l}\text { Dry weight } \\
\text { (g) }\end{array}$ & $\begin{array}{c}\text { Fresh weight } \\
\text { (g) }\end{array}$ & $\begin{array}{l}\text { Dry weight } \\
\text { (g) }\end{array}$ \\
\hline \multicolumn{2}{|c|}{ Coco peat $50 \%$} & $41.8 \mathrm{~b}$ & $7.6 \mathrm{c}$ & $146.6 \mathrm{~b}$ & $48.8 \mathrm{~b}$ & $690.0 \mathrm{c}$ & 195.6 c \\
\hline \multicolumn{2}{|c|}{$\begin{array}{l}\text { Coco peat } 40 \%+ \\
\quad \text { soil } 10 \%\end{array}$} & $41.0 \mathrm{~b}$ & $6.4 \mathrm{c}$ & $168.2 \mathrm{~b}$ & $45.8 \mathrm{~b}$ & $659.6 \mathrm{c}$ & 211.4 bc \\
\hline \multicolumn{2}{|c|}{$\begin{array}{l}\text { Coco peat } 30 \%+ \\
\quad \text { soil } 20 \%\end{array}$} & $44.7 \mathrm{~b}$ & $6.8 \mathrm{c}$ & $168.6 \mathrm{~b}$ & $52.0 \mathrm{~b}$ & $896.4 \mathrm{~b}$ & $207.0 \mathrm{bc}$ \\
\hline \multicolumn{2}{|c|}{$\begin{array}{l}\text { Coco peat } 20 \%+ \\
\quad \text { soil } 30 \%\end{array}$} & $42.5 \mathrm{~b}$ & $7.4 \mathrm{c}$ & $177.6 \mathrm{~b}$ & $45.4 \mathrm{~b}$ & $981.8 \mathrm{~b}$ & $203.0 \mathrm{bc}$ \\
\hline \multicolumn{2}{|c|}{$\begin{array}{l}\text { Coco peat } 10 \%+ \\
\quad \text { soil } 40 \%\end{array}$} & $58.1 \mathrm{a}$ & $14.2 \mathrm{~b}$ & $181.0 \mathrm{~b}$ & $49.6 \mathrm{~b}$ & $986.0 \mathrm{~b}$ & 222.6 b \\
\hline \multicolumn{2}{|c|}{ Soil 50\% } & $62.8 \mathrm{a}$ & $17.2 \mathrm{a}$ & $241.2 \mathrm{a}$ & $63.8 \mathrm{a}$ & $1218.4 \mathrm{a}$ & $311.2 \mathrm{a}$ \\
\hline \multicolumn{8}{|c|}{ Summary of the statistical analysis of the treatments } \\
\hline S.O.V. & $\mathrm{df}$ & \multicolumn{6}{|c|}{ Mean square } \\
\hline Substrate & 5 & $447.0^{* *}$ & $105.2^{* *}$ & $5135.3^{* *}$ & $230.0^{* *}$ & $217198^{* *}$ & $9293.4^{* *}$ \\
\hline Error & 24 & 50.72 & 2.08 & 772.1 & 28.45 & 5098.3 & 26.09 \\
\hline C.V & & 14.69 & 14.53 & 15.39 & 10.50 & 7.88 & 7.17 \\
\hline
\end{tabular}

Note: S.O.V: source of variation, df: degrees of freedom, C.V: coefficient of variation, ${ }^{* *} \mathrm{p}<0.01$. In each column, the values followed by at least one common character are not statistically different at $5 \%$ probability level, according to the Duncan test.

\subsection{Shoot Weight}

As shown at Table 3, the analysis of variance showed that the effect of substrate on fresh and dry weight of shoot was significant $(p<0.01)$. Statistical analysis showed fresh weight of shoot was far greater in soil 50\% compared to other growing media (Table 3). Also, lowest fresh weight of shoot was obtained in coco peat $50 \%$ and coco peat $40 \%+$ soil $10 \%$. The results showed that highest dry weight of shoot was observed in soil $50 \%$ compared to other growing media. Also, lowest dry weight of shoot was obtained in coco peat $50 \%$, although the difference between coco peat $50 \%$, with coco peat $10 \%$ + soil $40 \%$ was statistically different at $5 \%$ probability level, according to the Duncan test (Table 3).

\subsection{Nutrient Elements in Plant}

Table 4 presents the effect of different growing media on nutrient elements in plant. There was no significant effect of treatment on concentration of $\mathrm{P}$ and ranged from $0.066 \%$ to $0.072 \%$. As shown at Table 4 , the analysis of variance showed that the effect of substrate on concentration of $K$ was significant $(p<0.01)$. The concentration of $\mathrm{K}$ in coco peat $40 \%+$ soil $10 \%$ and soil $50 \%$ were lower than other growing media, although in some cases, the differences were not significant (Table 4). There were significant $(\mathrm{p}<0.01)$ differences between culture media in Ca concentration. The results showed that highest Ca concentration was observed in soil $50 \%$ and lowest concentration of this element was obtained in coco peat 50\%. As shown at Table 4, the analysis of variance showed that the effect of substrate on concentration of Fe and Zn was significant ( $<<0.01)$. The results showed that highest concentration of Fe and Zn was observed in coco peat $40 \%+$ soil $10 \%$ and lowest concentration of theses element was obtained in coco peat $20 \%+$ soil $30 \%$. There were significant $(\mathrm{p}<0.01)$ differences between culture media in concentration of $\mathrm{Mn}$. The concentration of $\mathrm{Mn}$ in coco peat $10 \%+$ soil $40 \%$ was higher than other growing media, however, lowest concentration of Mn was obtained in coco peat $50 \%$ and coco peat 20\% + soil 30\% (Table 4). 
Table 4. ANOVA model and comparison of some nutrient elements in plant for different growing media.

\begin{tabular}{|c|c|c|c|c|c|c|c|}
\hline \multirow{2}{*}{\multicolumn{2}{|c|}{ Growing media }} & \multicolumn{6}{|c|}{ Mean values plant properties for different growing media } \\
\hline & & $\mathrm{P}(\%)$ & K (\%) & $\mathrm{Ca}(\%)$ & $\mathrm{Fe}(\mathrm{mg} / \mathrm{kg})$ & $\operatorname{Mn}(\mathrm{mg} / \mathrm{kg})$ & $\mathrm{Zn}(\mathrm{mg} / \mathrm{kg})$ \\
\hline \multicolumn{2}{|c|}{ Coco peat $50 \%$} & 0.065 a & $1.50 \mathrm{a}$ & $0.24 \mathrm{f}$ & $41.3 \mathrm{~d}$ & $13.4 \mathrm{e}$ & $11.8 \mathrm{e}$ \\
\hline \multicolumn{2}{|c|}{$\begin{array}{c}\text { Coco peat } 40 \%+ \\
\text { soil } 10 \%\end{array}$} & $0.072 \mathrm{a}$ & $1.09 \mathrm{~b}$ & $0.74 \mathrm{~b}$ & 201.9 a & $38.2 \mathrm{c}$ & $57.2 \mathrm{a}$ \\
\hline \multicolumn{2}{|c|}{$\begin{array}{c}\text { Coco peat } 30 \%+ \\
\text { soil } 20 \%\end{array}$} & 0.066 a & $1.51 \mathrm{a}$ & $0.64 \mathrm{~d}$ & $72.5 \mathrm{c}$ & $32.1 \mathrm{~d}$ & $22.3 \mathrm{~d}$ \\
\hline \multicolumn{2}{|c|}{$\begin{array}{c}\text { Coco peat } 20 \%+ \\
\text { soil } 30 \%\end{array}$} & 0.067 a & $1.43 \mathrm{a}$ & $0.42 \mathrm{e}$ & 32.3 e & 15.3 e & $7.0 \mathrm{f}$ \\
\hline \multicolumn{2}{|c|}{$\begin{array}{c}\text { Coco peat } 10 \%+ \\
\text { soil } 40 \%\end{array}$} & $0.072 \mathrm{a}$ & $1.30 \mathrm{ab}$ & $0.66 \mathrm{c}$ & $95.3 \mathrm{~b}$ & $46.8 \mathrm{a}$ & $26.5 \mathrm{c}$ \\
\hline \multicolumn{2}{|c|}{ Soil $50 \%$} & 0.067 a & $1.11 \mathrm{~b}$ & $1.02 \mathrm{a}$ & $92.5 \mathrm{~b}$ & $41.3 \mathrm{~b}$ & $31.4 \mathrm{~b}$ \\
\hline \multicolumn{8}{|c|}{ Summary of the statistical analysis of the treatments } \\
\hline S.O.V. & df & \multicolumn{6}{|c|}{ Mean square } \\
\hline Substrate & 5 & $4.6 \times 10^{-5 n s}$ & $0.18^{* *}$ & $0.36^{* *}$ & $18560^{* *}$ & $964.8^{* *}$ & $1579^{* *}$ \\
\hline Error & 24 & $9.3 \times 10^{-5}$ & 0.04 & $7.5 \times 10^{-7}$ & 5.67 & 3.46 & 2.21 \\
\hline \multicolumn{2}{|c|}{ C.V. (\%) } & 14.16 & 15.58 & 0.14 & 2.67 & 5.97 & 5.71 \\
\hline
\end{tabular}

Note: S.O.V: source of variation, df: degrees of freedom, C.V: coefficient of variation, ${ }^{* *} \mathrm{p}<0.01$. In each column, the values followed by at least one common character are not statistically different at 5\% probability level, according to the Duncan test.

\subsection{Plant Chlorophyll Content}

Table 5 presents the effect of different growing media on plant chlorophyll (chlorophyll a, b and total chlorophyll) content. There was no significant effect of treatment on content of chlorophyll $a$, chlorophyll $b$ and total chlorophyll. The content of chlorophyll a ranged from 0.38 to $0.45 \mathrm{mg} / \mathrm{g}$ and for chlorophyll b ranged from 0.42 to $0.48 \mathrm{mg} / \mathrm{g}$. However, the content of total chlorophyll in coco peat $40 \%+$ soil $10 \%$ and soil $50 \%$ were higher than other growing media, although in some cases, the differences were not significant (Table 4).

\section{Discussion}

The type of growing media used in this study performed an important role in plant characteristics of carnation. The results showed that in most cases, the plant growth properties were significantly higher in mineral soil than other growing media. The increase in the characteristics of carnation with application of mineral soil can be explained on the basis of increases in concentration of nutrient elements. These results are concurred with the findings of Olympios [5] and Kumar and Goh [20] who discovered that physiochemical properties of growing media affected on plant growth and yield. The nutrient elements in the solution of different growing media are unique due to the different type and origin of media. Rostami et al. [21] reported that the highest yield and growth of strawberry possessed by date palm growing media. According to findings of Safaei et al. [22] the combination of NPK and manure fertilizers could be suggested as an appropriate nutrition source for thyme and the improvement of soil structure. However, perlite substrate with very low cation exchange capacity (CEC), and good capacity of water absorption and coco peat substrate, with its high water holding capacity and nutrients can be considered as good growing media in soilless culture [23]. Nowak and Strojny [24] confirmed that the total porosity, bulk density, and air capacity of the growing media had significant effects on growth of plant. Mohamadi-Ghehsareh et al. [3] found that fruit yield, shoot height and root weight of cucumber related to date-palm waste had a significant difference as compared with soil, however, this growing media had not significant difference as compared with perlite. The water holding capacity and aeration have likely an important role on plant growth and development [25]. 
Table 5. ANOVA model and comparison of some plant traits for different growing media.

\begin{tabular}{|c|c|c|c|c|}
\hline \multirow{3}{*}{\multicolumn{2}{|c|}{ Growing media }} & \multicolumn{3}{|c|}{ Mean values plant properties for different growing media } \\
\hline & & Chl a & Chl b & Total Chl \\
\hline & & \multicolumn{3}{|c|}{ (mg/g F.W) } \\
\hline \multicolumn{2}{|c|}{ Coco peat $50 \%$} & $0.41 \mathrm{a}$ & $0.45 \mathrm{a}$ & $0.86 a b$ \\
\hline \multicolumn{2}{|c|}{ Coco peat $40 \%+$ soil $10 \%$} & 0.45 a & $0.48 \mathrm{a}$ & $0.93 \mathrm{a}$ \\
\hline \multicolumn{2}{|c|}{ Coco peat $30 \%+$ soil $20 \%$} & 0.38 a & $0.42 \mathrm{a}$ & $0.80 \mathrm{~b}$ \\
\hline \multicolumn{2}{|c|}{ Coco peat $20 \%+$ soil $30 \%$} & $0.40 \mathrm{a}$ & 0.45 a & $0.85 \mathrm{ab}$ \\
\hline \multicolumn{2}{|c|}{ Coco peat $10 \%+$ soil $40 \%$} & $0.42 \mathrm{a}$ & $0.46 \mathrm{a}$ & $0.88 \mathrm{ab}$ \\
\hline \multicolumn{2}{|c|}{ Soil $50 \%$} & $0.45 \mathrm{a}$ & $0.48 \mathrm{a}$ & 0.93 a \\
\hline & & \multicolumn{3}{|c|}{ Summary of the statistical analysis of the treatments } \\
\hline S.O.V. & df & \multicolumn{3}{|c|}{ Mean square } \\
\hline Substrate & 5 & $0.003^{\text {ns }}$ & $0.003^{\text {ns }}$ & $0.012^{\mathrm{ns}}$ \\
\hline Error & 24 & 0.002 & 0.0025 & 0.007 \\
\hline \multicolumn{2}{|c|}{ C.V. (\%) } & 11.42 & 10.95 & 9.62 \\
\hline
\end{tabular}

Note: S.O.V: source of variation, df: degrees of freedom, C.V: coefficient of variation, ns: not significant, ${ }^{* *} \mathrm{p}<0.01$. In each column, the values followed by at least one common character are not statistically different at $5 \%$ probability level, according to the Duncan test.

The results showed that highest concentration of Fe and $\mathrm{Zn}$ was observed in coco peat $40 \%+$ soil $10 \%$. The concentration of $\mathrm{Mn}$ in coco peat $10 \%+$ soil $40 \%$ was higher than other growing media. The results showed that highest Ca concentration was observed in soil $50 \%$ and lowest concentration of this element was obtained in coco peat 50\%. Kalantari et al. [26] reported that vermicompost increased the concentrations of $\mathrm{P}, \mathrm{K}, \mathrm{Ca}$, and $\mathrm{Mg}$ in the shoot of corn. However, Stamatiadis et al. [27] stated that the concentrations N, P, K, Ca, Mg, Zn, Fe in broccoli leaves were not significant in control, compost and ammonium nitrate treatments.

There was no significant effect of treatment on content of chlorophyll a, chlorophyll b and total chlorophyll. The content of plant chlorophyll reflects the photosynthetic assimilation ability and photosynthetic rate [28]. In contrast with findings obtained in present study, Doan et al. [29] found that chlorophyll content maize leaves was greater in control compared to the compost and vermicompost treatments. Also, Fernández-Luqueño et al. [30] illustrated that the chlorophyll content of the beans in the vermicompost was higher than sludge and urea.

\section{Conclusion}

The performance and suitability of different medium for the carnation (Dianthus caryophyllus L.) were studied by employing six different substrates in a greenhouse. It is evident from the results that application of mineral soil (the combination with perlite) as growing media can support better carnation growth, when compared to the coco peat.

\section{References}

[1] Chopra, R.N., Mayar, S.L. and Chopra, I.C. (1986) Glossary of Indian Medicinal Plants (Including the Supplement). Council of Scientific and Industrial Research, New Delhi.

[2] Awang, Y., Shaharom, A.S., Mohamad, R.B. and Selamat, A. (2009) Chemical and Physical Characteristics of Cocopeat-Based Media Mixtures and Their Effects on the Growth and Development of Celosia cristata. American Journal of Agricultural and Biological Sciences, 4, 63-71. http://dx.doi.org/10.3844/ajabssp.2009.63.71

[3] Mohamadi-Ghehsareh, A., Hematian, M. and Kalbasi, M. (2012) Comparison of Date-Palm Wastes and Perlite as Culture Substrates on Growing Indices in Greenhouse Cucumber. International Journal of Recycling of Organic Waste in Agriculture, 1, 5. http://dx.doi.org/10.1186/2251-7715-1-5

[4] Caballero, R., Ordovás, J., Pajuelo, P., Carmona, E. and Delgado, A. (2007) Iron Chlorosis in Gerber as Related to Properties of Various Types of Compost Used as Growing Media. Communications in Soil Science and Plant Analysis, 38, 2357-2369. http://dx.doi.org/10.1080/00103620701588494 
[5] Olympios, C.M. (1992) Soilless Media under Protected Cultivation. Rockwool, Peat, Perlite and Other Substrates. Acta Horticulturae, 323, 215-235.

[6] Omidbaigi, R. and Arjmandi, A. (2002) Effects of NP Supply on Growth, Development, Yields and Active Substances of Garden Thyme (Thymus vulgaris L.). Acta Horticulture, 576, 263-265. http://dx.doi.org/10.17660/ActaHortic.2002.576.38

[7] Baranauskiene, R., Venskutonis, P.R., Viskelis, P. and Dambrauskiene, E. (2003) Influence of Nitrogen Fertilizers on the Yield and Composition of Thyme (Thymus vulgaris). Journal of Agricultural and Food Chemistry, 51, 7751-7758. http://dx.doi.org/10.1021/jf0303316

[8] Edris, M.A., Shalaby, A. and Fadel, H.M. (2003) Effect of Organic Agriculture Practices on the Volatile Aroma Components of Some Essential Oil Plants Growing in Egypt II. Sweet Marjoram (Origanum marijorana L.) Essential Oil. Flavour and Fragrance Journal, 18, 345-351. http://dx.doi.org/10.1002/ffj.1235

[9] Hendawy, S.F., Azza, A.E., Aziz, E. and Omer, E.A. (2010) Productivity and Oil Quality of Thymus vulgaris L. under Organic Fertilization Conditions. Ozean Journal of Applied Sciences, 3, 203-216.

[10] Samiei, L., KHalighi, A., Kafi, M., Samavat, S. and Arghavani, M. (2005) An Investigation of Substitution of Peat Moss with Palm Tree Celluloid Wastes in Growing Aglaonema (Aglaonema commutatum Cv. Silver Queen). Iranian Journal Agriculture Science, 36, 503-510. (In Persian)

[11] Nyamangara, J., Bergstrom, L.F., Piha, M.I. and Giller, K.E. (2003) Fertilizer Use Efficiency and Nitrate Leaching in a Tropical Sandy Soil. Journal of Environmental Quality, 32, 599-606. http://dx.doi.org/10.2134/jeq2003.5990

[12] Naeem, M., Iqbal, J. and Bakhsh, M.A.A. (2006) Comparative Study of Inorganic Fertilizers and Organic Manures on Yield and Yield Components of Mungbean (Vigna radiat L.). Journal of Agriculture and Social Sciences, 2, 227-229.

[13] Suresh, K.D., Sneh, G., Krishn, K.K. and Mool, C.M. (2004) Microbial Biomass Carbon and Microbial Activities of Soils Receiving Chemical Fertilizers and Organic Amendments. Archives Agronomy Soil Science, 50, 641-647. http://dx.doi.org/10.1080/08927010400011294

[14] Dauda, S.N., Ajayi, F.A. and Ndor, E. (2008) Growth and Yield of Water Melon (Citrullus lanatus) as Affected by Poultry Manure Application. Journal of Agriculture and Social Sciences, 4, 121-124.

[15] Baruah, T.C. and Barthakur, H.P. (1997) A Textook of Soil Chemical Analysis. Vikas Publishing House Pvt. Ltd., New Delhi, 282.

[16] Verdonck, O. and Gabriels, R. (1992) Reference Method for the Determination of Physical Properties of Plant Substrates. II. Reference Method for the Determination of Chemical Properties of Plant Substrates. Acta Horticulturae, 302, 169-179. http://dx.doi.org/10.17660/ActaHortic.1992.302.16

[17] Daifullah, A.A.M., Girgis, B.S. and Gad, H.M.H. (2003) Utilization of Agro-Residues (Rice Husk) in Small Waste Water Treatment Plans. Materials Letters, 57, 1723-1731. http://dx.doi.org/10.1016/S0167-577X(02)01058-3

[18] Gee, G.W. and Bauder, J.W. (1986) Particle-Size Analysis. In: Klute, A., Ed., Methods of Soil Analysis, Part 1: Physical and Mineralogical Methods, Agronomy Monograph No. 9, 2nd Edition, American Society of Agronomy, Madison.

[19] Arnon, D.I. (1949) Copper Enzymes in Isolated Chloropl Asts, Polyphenoxidase in Beta Vulgaris. Plant Physiology, 24, 1-15. http://dx.doi.org/10.1104/pp.24.1.1

[20] Kumar, K. and Goh, K.M. (1999) Crop Residues and Management Practices: Effects on Soil Quality, Soil Nitrogen Dynamics, Crop Yield, and Nitrogen Recovery. Advances in Agronomy, 68, 197-319. http://dx.doi.org/10.1016/S0065-2113(08)60846-9

[21] Rostami, Z., Mohammadi Ghehsareh, A. and Bijan, K. (2014) Date Palm Waste Application as Culture Media for Strawberry and Its Impact on Some Growth Indices and Yield Components. Agricultural Communications, 2, 15-21.

[22] Safaei, L., Sharifi Ashoorabadi, E., Afiuni, D., Davazdah Emami, S. and Shoaii, A. (2014) The Effect of Different Nutrition Systems on Aerial Parts and Essential Oil Yield of Thymus daenensis Celak. Iranian Journal of Medicinal and Aromatic Plants, 30, 702-713.

[23] Djedidi, M., Gerasopoulos, D. and Maloupa, E. (1999) The Effect of Different Substrates on the Quality of “Carmelo” Tomatoes (Lycopersicom esculentum Mill.) Grown under Protection in a Hydroponic System. Cahier Option Mediterranneenes, 31, 379-383.

[24] Nowak, J. and Strojny, Z. (2004) The Effect of Physical Properties of Organic Growing Medium on Cut Flower Yield of Gerbera. Folia Universitatis Agriculturae Stetinensis, Agricultura, 94, 133-138.

[25] Dewayne, L.I., Richard, W.H. and Thomas, H.Y. (2003) Growth Media for Container Grown Ornamental Plants. The Environmental Horticulture Department, Florida Cooperative Extension Service, Institute of Food and Agricultural Sciences, University of Florida, BUL241.

[26] Kalantari, S., Hatami, S., Ardalan, M.M., Alikhani, H.A. and Shorafa, M. (2010) The Effect of Compost and Vermicompost of Yard Leaf Manure on Growth of Corn. African Journal of Agricultural Research, 5, 1317-1323. 
[27] Stamatiadis, S., Werner, M. and Buchanan, M. (1999) Field Assessment of Soil Quality as Affected by Compost and Fertilizer Application in a Broccoli Field (San Benito County, California). Applied Soil Ecology, 12, 217-225. http://dx.doi.org/10.1016/S0929-1393(99)00013-X

[28] Liu, C.H., Liu, Y., Fan, C. and Kuang, S.Z. (2013) The Effects of Composted Pineapple Residue Return on Soil Properties and the Growth and Yield of Pineapple. Journal of Soil Science and Plant Nutrition, 13, 433-444.

[29] Doan, T.T., Ngo, T.P., Rumpel, C., Nguyen, V.B. and Jouquet, P. (2013) Interactions between Compost, Vermicompost and Earthworm Influence Plant Growth and Yield. A One Year Greenhouse Experiment. Scientia Horticulturae, 160, 148-154. http://dx.doi.org/10.1016/j.scienta.2013.05.042

[30] Fernández-Luqueño, F., Reyes-Varela, V., Martínez-Suárez, C., Salomón-Hernández, G., Yáñez-Meneses, J., Ceballos-Ramírez, J.M. and Dendooven, L. (2010) Effect of Different Nitrogen Sources on Plant Characteristics and Yield of Common Bean (Phaseolus vulgaris L.). Bioresource Technology, 101, 396-403. http://dx.doi.org/10.1016/j.biortech.2009.07.058 